\title{
Mechanisms of Taste Bud Cell Loss after Head and Neck Irradiation
}

\author{
Ha M. Nguyen, ${ }^{1,2,3}$ Mary E. Reyland, ${ }^{3,4}$ and Linda A. Barlow ${ }^{1,2,3}$ \\ ${ }^{1}$ Department of Cell and Developmental Biology, School of Medicine, ${ }^{2}$ Rocky Mountain Taste and Smell Center, ${ }^{3}$ Graduate Program in Cell Biology, Stem \\ Cells and Development, and ${ }^{4}$ Department of Craniofacial Biology, School of Dental Medicine, University of Colorado, Anschutz Medical Campus, Aurora, CO \\ 80045
}

Taste loss in human patients following radiotherapy for head and neck cancer is a common and significant problem, but the cellular mechanisms underlying this loss are not understood. Taste stimuli are transduced by receptor cells within taste buds, and like epidermal cells, taste cells are regularly replaced throughout adult life. This renewal relies on progenitor cells adjacent to taste buds, which continually supply new cells to each bud. Here we treated adult mice with a single 8 Gy dose of x-ray irradiation to the head and neck, and analyzed taste epithelium at 1-21 d postirradiation (dpi). We found irradiation targets the taste progenitor cells, which undergo cell cycle arrest (1-3 dpi) and apoptosis (within $1 \mathrm{dpi}$ ). Taste progenitors resume proliferation at 5-7 dpi, with the proportion of cells in $\mathrm{S}$ and $\mathrm{M}$ phase exceeding control levels at 5- 6 and $6 \mathrm{dpi}$, respectively, suggesting that proliferation is accelerated and/or synchronized following radiation damage. Using 5-bromo-2-deoxyuridine birthdating to identify newborn cells, we found that the decreased proliferation following irradiation reduces the influx of cells at 1-2 dpi, while the robust proliferation detected at 6 dpi accelerates entry of new cells into taste buds. In contrast, the number of differentiated taste cells was not significantly reduced until 7 dpi. These data suggest a model where continued natural taste cell death, paired with temporary interruption of cell replacement, underlies taste loss after irradiation.

\section{Introduction}

The sense of taste is mediated by taste buds in the oral cavity. Taste buds are multicellular receptor organs containing 60-100 cells, which are continually renewed by progenitor cells located at the basement membrane and along the lateral margins of buds (Beidler and Smallman, 1965; Miura et al., 2003; Hamamichi et al., 2006). After their terminal division, immature taste cells enter buds and differentiate into one of three taste cell types. Type I cells are glial like, and express the glutamate-aspartate transporter and the ecto-ATPase, NTPDase 2 (Pumplin et al., 1999; Lawton et al., 2000; Bartel et al., 2006); type I cells may also function in salt taste transduction (Vandenbeuch et al., 2008). Type II or "receptor" cells transduce sweet, bitter, and umami stimuli (Bernhardt et al., 1996; Miyoshi et al., 2001; Zhang et al., 2003; Clapp et al., 2006) and express transduction elements for

Received Aug. 12, 2011; revised Jan. 20, 2012; accepted Jan. 21, 2012.

Author contributions: H.M.N., M.E.R., and L.A.B. designed research; H.M.N. performed research; H.M.N. and L.A.B. analyzed data; H.M.N., M.E.R., and L.A.B. wrote the paper.

This work was supported by R01 DC003947 (L.A.B.), P30 DC004657 to Diego Restrepo, and a Vietnam Education Foundation fellowship (H.M.N.).We thank Dr. Emily Liman (University of Southern California) for the Trpm5 antiserum, Jennifer K. Scott, Greg Banninger, and especially Brendan Ross for technical assistance, and Hirohito Miura for invaluable advice, good humor, and expertise during his sabbatical year in the Barlow Laboratory. Thanks to Drs. Tom Finger, Sue Kinnamon, Dany Gaillard, and Shoba Thirumangalathu for excellent comments on earlier versions of the manuscript, and to the Rocky Mountain Taste and Smell Center for mouse, imaging, and statistical support, especially advice from Dr. Rob Hallock.

Correspondence should be addressed to Linda A. Barlow, University of Colorado, Anschutz Medical Campus, Department of Cell and Developmental Biology, Mail Stop 8108, 12801 East 17th Ave, Aurora, C0 80045. E-mail: linda.barlow@ucdenver.edu.

Ha M. Nguyen's present address: Hanoi Medical University, Department of Histology and Embryology, No. 1 Ton That Tung, Hanoi, Vietnam.

DOI:10.1523/JNEUROSCI.4167-11.2012

Copyright $\odot 2012$ the authors $\quad 0270-6474 / 12 / 323474-11 \$ 15.00 / 0$ these tastants, including $\alpha$-gustducin, phospholipase $\mathrm{C} \beta 2$ Boughter et al., 1997; Clapp et al., 2004), $\mathrm{IP}_{3} \mathrm{R} 3$ (Clapp et al., 2001), and Trpm5 (Clapp et al., 2006). Type III cells detect sour (Huang et al., 2006; Kataoka et al., 2008) and are the only cell type to synapse with afferent nerves (Murray, 1986; Yee et al., 2001; Yang et al., 2007); therefore, they have been considered "presynaptic" cells (Chaudhari and Roper, 2010). Type III cells express NCAM (Takeda et al., 1992), SNAP-25 (Yang et al., 2000), and Car4 (Chandrashekar et al., 2009) and accumulate serotonin (Huang et al., 2005; Dvoryanchikov et al., 2007). Despite differences in function, all three types are thought to live for 10-14 d (Farbman, 1980) and then undergo apoptosis (Zeng and Oakley, 1999; Zeng et al., 2000; Huang and Lu, 2001; Wang et al., 2007; Ichimori et al., 2009). In this way, cells within buds are continually renewed.

Taste dysfunction after radiotherapy for head and neck cancer is a common problem for patients (Schwartz et al., 1993; Vissink et al., 2003; Sandow et al., 2006; Yamashita et al., 2009). During a 6- to 8-week course of daily radiotherapy, taste loss typically occurs by 3-4 weeks, and all taste modalities are commonly affected (Mossman and Henkin, 1978; Maes et al., 2002; Ruo Redda and Allis, 2006; Sandow et al., 2006). Distorted taste, combined with other oral dysfunctions after irradiation (xerostomia, mucositis), can dramatically and negatively affect human nutrition (Donaldson, 1977; Jensen et al., 2003).

Three models have been proposed to explain irradiationtriggered taste dysfunction: (1) neurites that innervate sensory organs are radiosensitive, thus disruption of the contact between taste cells and nerves leads to taste cell death; (2) irradiation directly damages differentiated taste cells; and/or (3) irradiation targets proliferating progenitors, interrupting production of new 

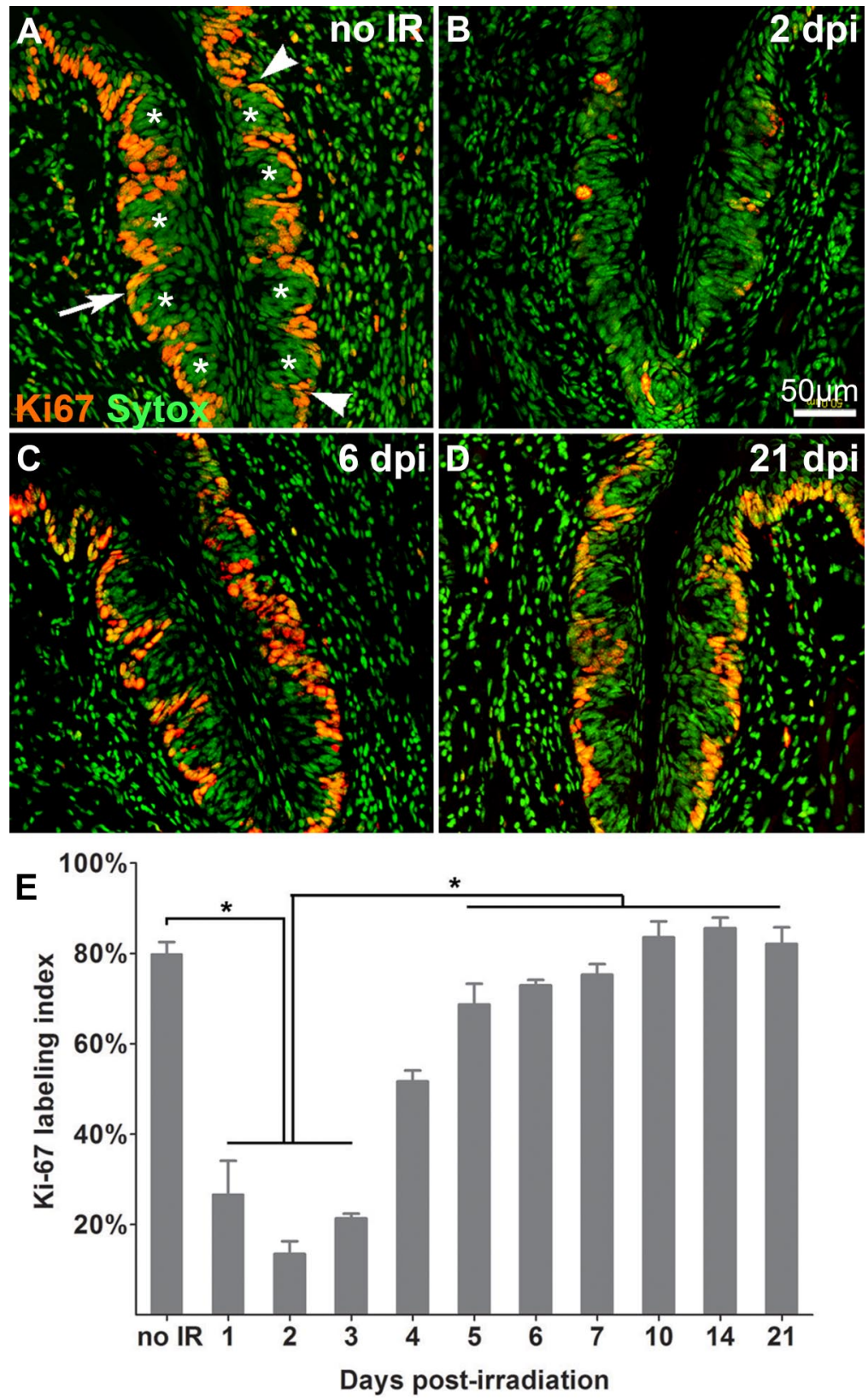

Figure 1. Irradiation targets actively cycling cells. Proliferative cells in taste epithelium are marked by Ki-67-IR (red) and nuclei are visualized with Sytox (green). Compared with controls $(\boldsymbol{A})$, the number of basal proliferative cells is significantly reduced at 1-3 $\mathrm{dpi}(\boldsymbol{B}, \boldsymbol{E})$, then returns to and is maintained at control levels from 5 to $21 \mathrm{dpi}(\boldsymbol{C}, 6 \mathrm{dpi} ; \boldsymbol{D}, 21 \mathrm{dpi})$. White asterisks indicate taste buds. White arrows indicate active cycling cells in basal epithelium. Total basal epithelial cell nuclei and Ki-67-IR cells were counted between the arrowheads in each trench. $E$, Bar graph of the proportion of Ki-67-IR basal epithelial cells at progressive time points after irradiation (mean $\pm S D ; n=3-5$ mice for each time; one-way ANOVA, Tukey's post hoc test, ${ }^{*} p<0.01$.

taste cells (Nelson, 1998; Yamazaki et al., 2009). Here we show that a single moderate dose of irradiation causes immediate cell cycle arrest in taste progenitors, followed by disruption in the supply of new cells to taste buds, which results in reduced taste cell number a week after radiation exposure. We propose that disrupted taste cell renewal is the primary mechanism responsible for functional taste loss in patients receiving radiotherapy.

\section{Materials and Methods}

Animals. Two- to four-month-old C57BL/6 mice of either sex were used in all experiments. Mice were maintained and killed in accordance with protocols approved by the Animal Care and Use Committee at the University of Colorado School of Medicine.

Irradiation. X-ray irradiation was delivered via an RS 2000 Biological Irradiator. Before irradiation, the mice were anesthetized with fresh Avertin (0.5 mg/g mouse, i.p.), and the body was shielded with lead, leaving only the head and neck exposed. In pilot experiments, we found that the typical 16 Gy dose used by others (Nelson, 1998; Yamazaki et al., 2009) resulted in $50 \%$ mortality by $1 \mathrm{~d}$ postirradiation (dpi), and all animals were dead within 2 weeks (data not shown). We also tested lower doses of 1,2 , or $4 \mathrm{~Gy}$, which were well tolerated by the mice, and produced similar, but smaller effects than the selected 8 Gy dose. The 8 Gy dose was selected for further investigation as this dose was not lethal over the experimental period of $21 \mathrm{~d}$, yet triggered a robust response in taste epithelium. Dose administration was calculated and adjusted by a dosimeter.

Tissue preparation. Mice were anesthetized as above, and perfused transcardially with $4 \%$ paraformaldehyde in $0.1 \mathrm{M}$ phosphate buffer (PFA). Tongues were dissected ad libitum from the lower jaw, and postfixed in 4\% PFA overnight at $4^{\circ} \mathrm{C}$, followed by immersion in sucrose $(20 \%$ in $0.1 \mathrm{M} \mathrm{PB})$ overnight at $4^{\circ} \mathrm{C}$. Cryoprotected tongues were embedded in OCT compound (Tissue-Tek) and cryosectioned at 12 $\mu \mathrm{m}$. Sections were thaw-mounted and stored at $-20^{\circ} \mathrm{C}$ overnight before staining.

Immunofluorescence for taste cells. Sections were rehydrated in $0.1 \mathrm{M}$ PBS for $30 \mathrm{~min}$, and blocked with blocking solution ( $0.2 \mathrm{M}$ PB, 0.05 $\mathrm{M} \mathrm{NaCl}, 0.1 \%$ Triton X-100; $1 \%$ BSA) with $5 \%$ normal goat serum (NSG) for $2 \mathrm{~h}$ at room temperature (except for goat anti-Car4 antiserum). Sections were then incubated overnight at $4^{\circ} \mathrm{C}$ in primary antiserum diluted in blocking solution without goat serum. Antisera include: (1) rabbit anti-Gustducin (1:1000; catalog \#sc-395,Santa Cruz Biotechnology); (2) rabbit anti-Trpm5 (1: 1000; gift from Dr. Emily Liman, University of Southern California); or (3) goat anti-Car4 (1: 1000; catalog \#AF2414, R\&D Systems). Sections were then washed with PBS for $2 \mathrm{~h}$, and incubated in the appropriate secondary antiserum (goat anti-rabbit Alexa Fluor 546 (1:1000; Invitrogen) or donkey anti-goat Alexa Fluor 546 (1:1000; Invitrogen) in blocking solution for $2 \mathrm{~h}$ at room temperature. Sections were washed in $0.1 \mathrm{~m}$ PBS for $2 \mathrm{~h}$, counterstained with Sytox (Invitrogen), mounted in Fluoromount G, and coverslipped for analysis using fluorescence and confocal microscopy.

Immunofluorescence for cell cycle markers. The method for phospho-histone3 (pH3) immunostaining has been described (Nguyen and Barlow, 2010). For Ki-67 immunofluorescence, sections were washed thrice in $0.1 \mathrm{M}$ PBS, treated with sodium citrate buffer, $\mathrm{pH} 6.0$, at $95^{\circ} \mathrm{C}$ for $15 \mathrm{~min}$, and cooled to room temperature for 30 min. Sections were then washed in PBS and incubated in blocking solution with $5 \%$ NSG for $2 \mathrm{~h}$ at room temperature followed by $15 \mathrm{~min}$ each for avidin/biotin blocking solutions (A/B blocking Kit; Vector Laboratories). Sections were then incubated in rabbit anti-Ki-67 antiserum (1:200; Thermo Scientific) overnight at $4^{\circ} \mathrm{C}$. After three washes with PBS buffer for $1 \mathrm{~h}$ each, sections were incubated with biotin-conjugated anti-rabbit IgG (Vector Laboratories) diluted 1:500 in PBS with 0.1\% Tween 20 and 

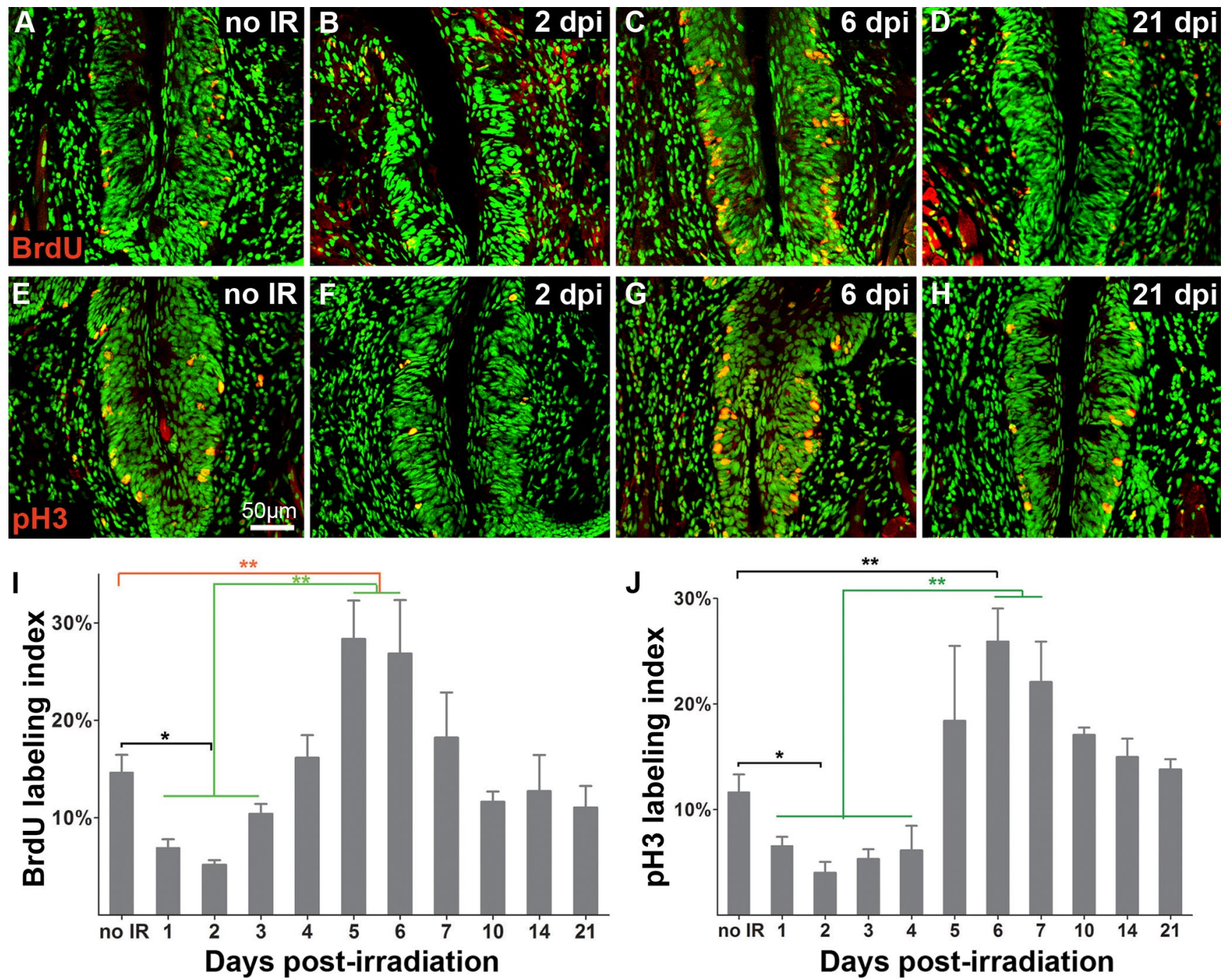

Figure 2. The proportions of cells in $S$ and $M$ phase drop following irradiation, then overshoot control levels, before returning to normal values. Cells in $S$ phase in controls and at selected times postirradiation are identified via nuclear incorporation of $\mathrm{BrdU}(\boldsymbol{A}-\boldsymbol{D} ; \mathrm{BrdU}-\mathrm{IR}$, red) and those in $\mathrm{M}$ phase are immunoreactive for pH3 $(\boldsymbol{E}-\boldsymbol{H} ; \mathrm{pH} 3-\mathrm{IR}$, red). $\boldsymbol{A}-\boldsymbol{D}$, Sham-irradiated controls, 2, 6, and 21 dpi. $\boldsymbol{E}-\boldsymbol{H}$, Sham-irradiated controls, 2, 6, and 21 dpi. Histograms for $S(\boldsymbol{I})$ and $M(\boldsymbol{J})$ phase show labeling indices of sham-irradiated epithelium versus that of epithelium harvested at progressive times postirradiation. The proportion of basal cells in both $S$ and $M$ phases are significantly decreased at 2 dpi. Significantly more basal cells are in $S$ phase at $5-6$ dpi compared with controls; the proportion in $\mathrm{M}$ phase also overshoots controls at $6 \mathrm{dpi}(\mathbf{G}, J)$. Both indices are comparable to controls from $7 \mathrm{dpi}$ onward. One-way ANOVA, Tukey's posthoc test; $n=3-4$ mice for each time point; ${ }^{*} p<0.05 ;{ }^{* *} p<0.01$.

$2.5 \%$ NSG for $1 \mathrm{~h}$ at room temperature. Sections were washed with PBS for $1 \mathrm{~h}$, then incubated in Streptavidin 546 (1:1000; Millipore Bioscience Research Reagents) in PBS buffer for $2 \mathrm{~h}$ at room temperature. After final washes in PBS for $1 \mathrm{~h}$, sections were counterstained with Sytox green (Invitrogen) and mounted in Fluoromount G (Southern Biotech).

For 5-bromo-2-deoxyuridine (BrdU) immunofluorescence, sections were washed in $1 \mathrm{~T}$ buffer $(0.1 \mathrm{M}$ Tris, $\mathrm{pH} 7.5,0.15 \mathrm{M} \mathrm{NaCl})$, then incubated in a solution of 50\% formamide and 5X SSC. After three washes in $1 \mathrm{~T}$ buffer, sections were blocked in $1 \%$ blocking reagent in $1 \mathrm{~T}$ buffer for $30 \mathrm{~min}$ at room temperature. Anti-BrdU monoclonal antibody $(2 \mu \mathrm{g} / \mathrm{ml}$; catalog \#10875400, Roche) was applied to tissues together with DNaseI (10 UI/ml; Roche) for $50 \mathrm{~min}$ at $37^{\circ} \mathrm{C}$. Sections were washed with $1 \mathrm{~T}$ buffer, and incubated with goat-anti-mouse Alexa Fluor 546 for $1 \mathrm{~h}$ at room temperature. After washing, sections were counterstained with Sytox green and mounted.

TUNEL assay. TUNEL was performed using the In Situ Cell Death Detection Kit TMR Red (Roche Applied Science). After three washes in PBS, sections were treated with $3 \%$ hydrogen peroxide in methanol, bathed in sodium citrate buffer, $\mathrm{pH} 6.0$, at $95^{\circ} \mathrm{C}$ for $15 \mathrm{~min}$, and then cooled to room temperature for $40 \mathrm{~min}$. Sections were washed in PBS and permeabilized for $2 \mathrm{~min}$ on ice in a solution of $0.1 \%$ Triton X-100 and $0.1 \%$ sodium citrate. Sections were incubated in blocking solution $(20 \%$ NSG, 3\% BSA, Tris- $\mathrm{HCl} 50 \mathrm{~mm}$ at $\mathrm{pH}$ 7.5) for $30 \mathrm{~min}$. After washing in PBS for $30 \mathrm{~min}$, sections were incubated for $1 \mathrm{~h}$ at $37^{\circ} \mathrm{C}$ with $10 \%$ enzyme solution diluted in buffer solution (Roche kit). Sections were washed in $0.1 \mathrm{M}$ PBS for $1 \mathrm{~h}$, counterstained with Sytox green (Invitrogen), mounted in Fluoromount G, and coverslipped for analysis using fluorescence and confocal microscopy.

Birthdating of new taste cells. Mice were injected intraperitoneally with $\operatorname{BrdU}(120 \mathrm{mg} / \mathrm{kg}$; Sigma) twice, at 10 A.M. and at 1 P.M. For the three different series of birthdating experiments, BrdU injections were as follows: (1) the first BrdU dose was injected $6 \mathrm{~h}$ before irradiation, and mice were then killed at 1 or 2 dpi (see Fig. 4); (2) the first BrdU dose was injected at $5 \mathrm{dpi}$, and mice killed at 6 or $7 \mathrm{dpi}$ (see Fig. $6 \mathrm{~A}-\mathrm{E}$ ); or (3) the first BrdU dose was injected at $6 \mathrm{dpi}$, and mice killed at 7 or $8 \mathrm{dpi}$ (Fig. $6 F-J)$. Tongue cryosections (as above) from these mice were incubated in $90 \%$ methanol containing $3 \%$ hydrogen peroxide, washed in PBS, and then treated with $0.05 \%$ trypsin solution $\left(37^{\circ} \mathrm{C}\right.$ for $\left.5 \mathrm{~min}\right)$. After washing in PBS, sections were treated with $4 \mathrm{~N} \mathrm{HCl}$ at $50^{\circ} \mathrm{C}$ for $15 \mathrm{~min}$, then blocked with M.O.M. mouse Ig blocking reagent ( $1 \mathrm{~h}$ at room tempera- 

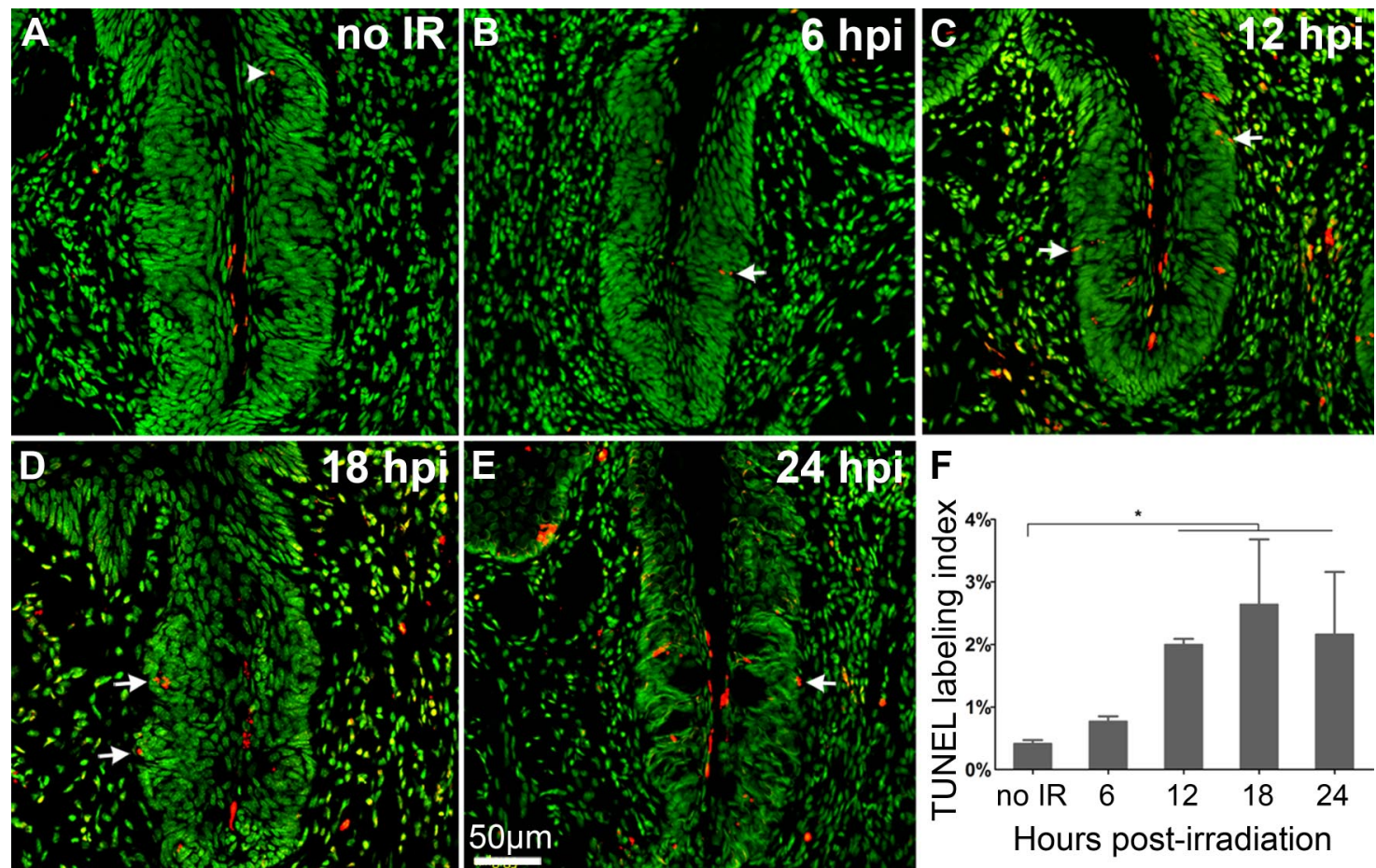

Figure 3. Irradiation induces apoptosis in basal keratinocytes of the taste epithelium. TUNEL (red) and Sytox (green) in sham-irradiated $(\boldsymbol{A})$, and at $6(\boldsymbol{B}), 12(\boldsymbol{C}), 18(\boldsymbol{D})$, and $24(\boldsymbol{E})$ hpi. In sham-irradiated controls, very few apoptotic cells are observed in taste epithelium; TUNEL-positive cells, when present, were located within taste buds (white arrowhead). Following irradiation, the number of apoptotic cells increased, and most were located at the basement membrane (white arrows point to examples). $\boldsymbol{F}$, The number of TUNEL + cells peaked at $18 \mathrm{hpi}$. One-way ANOVA, Tukey's post hoc test; $n=3-5$ mice per time point; ${ }^{*} p<0.01$.

ture; Vector Laboratories), and incubated overnight at $4^{\circ} \mathrm{C}$ with mouse anti-BrdU (1:500; catalog \#G3G4, Developmental Studies Hybridoma Bank). After washing with PBS for $3 \mathrm{~h}$, sections were blocked in avidin/ biotin blocking solutions (A/B blocking Kit; Vector Laboratories), incubated for $60 \mathrm{~min}$ with biotin-conjugated anti-mouse IgG (1:500; Vector Laboratories), washed for $1 \mathrm{~h}$ in PBS, and then incubated in ABC solution (Vector Laboratories) for $90 \mathrm{~min}$ at room temperature. Sections were washed for $1 \mathrm{~h}$, reacted with nickel-intensified DAB (Vector Laboratories) for 6-10 min, dehydrated with ethanol (50, 70, 95, and 100\%), rinsed in xylene, and coverslipped with Permount (Fisher Scientific). Newborn cells within taste buds were also identified using BrdU immunofluorescence and Sytox nuclear counterstain (see above).

Analysis. Immunofluorescent images were obtained on an Olympus BX50 laser-scanning confocal microscope. Images consisting of projected $\mathrm{Z}$ series of $0.75 \mu \mathrm{m}$ optical sections were processed with Fluoview v5.0 software. Nomarski images were obtained with a Zeiss Axioplan 2 microscope equipped with an Axiocam cooled CCD camera and Axiovision imaging software.

The data for this study were gathered from three to six mice per time point. All quantitative measures of cells within taste buds were taken from taste bud profiles with taste pores or the middle profile of taste buds based on serial sections. For the entire study, all tallies and cell position assignments were done blind with respect to treatment and animal. Slides were identified only by number, and not by the details of experimental or control treatment. The data were decoded and analyzed only after all tallies had been made.

The labeling index for each proliferation marker was calculated by dividing the number of immunopositive cells for each marker, e.g., Ki-67 immunoreactive (Ki-67-IR), BrdU-IR, or pH3-IR, by the total number of basal epithelial cells (identified and quantified via Sytox labeling). Only basal keratinocytes along the basement membrane and within the trenches of circumvallate papillae (CVP) that contain taste buds (Fig. 1, basal keratinocytes lying between the arrowheads) were counted.

For BrdU birthdating studies, the border of taste buds was determined by (1) Nomarski imaging and (2) fluorescence of Sytox green-stained nuclei. To include counts from individual taste bud profiles, each profile had to meet the following criteria: (1) the taste bud profile extended from the base of epithelium to its apex and (2) if a taste bud extended across multiple sections, the middle, and therefore largest profile was selected, so that the counted profiles represent approximately the center of each taste bud. Only taste buds with clear borders were tallied in our analyses (Figs. 4 and 6, taste buds with outlines). We then counted the number of BrdU-IR nuclei within each taste bud. Edge cells with elongate nuclei were considered to be outside of taste buds, whereas recently generated $(24-48 \mathrm{~h}) \mathrm{BrdU}+$ taste bud cells were located inside the basal compartment of each bud (Figs. $4 A, B, 6 A, C, F)$. BrdU + cells outside of taste buds were also found in the basal and suprabasal compartments of nontaste epithelium within the CVP (Figs. 4, 6, examples in all panels).

In pilot studies comparing the average nuclear diameter of control basal epithelial cells with those from irradiated mice at 1, 3, and 5 dpi, we found that nuclear size varied significantly with radiation exposure (oneway ANOVA, $n=3$ mice per time point, $p=0.02$ ). Thus to normalize the data across experimental conditions, we used Abercrombie correction (Abercrombie, 1946) as follows: Z-stack projections with a total depth of $9.75 \mu \mathrm{m}$ were obtained from $0.75 \mu \mathrm{m}$ optical sections of $12 \mu \mathrm{m}$ physical sections. The top and bottom optical sections were discarded to make sure tallied optical planes were physically complete, thus minimizing any problems due to variation in section thickness. The nuclear diameter parallel to the basal membrane, and thus perpendicular to the plane of section, of 20 randomly selected basal epithelial cells (enumerated and then selected via a random number generator) was measured and averaged. This average diameter for each condition was used in the Abercrombie formula using a section thickness of $9.75 \mu \mathrm{m}$. As cell cycle phase correlates with nuclear size, we reasoned that each marker class could comprise a subset of similarly sized nuclei whose average diameter would be distinct from that of the total basal population. In fact, we found that the average nuclear diameter for cells at different phases of the cell cycle, and thus the Abercrombie correction factor, was distinct from that of the Sytox population as a whole. Therefore, we elected to also correct counts for all markers at each time postirradiation.

A $t$ test or one-way ANOVA with a Tukey's post hoc multiplecomparison test was used to analyze data after ascertaining the data were 
normally distributed using the Anderson-Darling test. Data are presented as mean \pm SD unless otherwise noted.

\section{Results}

\section{Irradiation targets actively cycling cells}

For our studies, we focused on the CVP, a large structure located at the posterior midline of the mouse tongue. The papilla is surrounded bilaterally by deep epithelial trenches, and each trench contains $\sim 150$ taste buds. Thus, the CVP provides an anatomically focused set of taste buds to monitor for the effects of radiation exposure, including taste progenitor proliferative activity. Several immunomarkers were used to identify proliferating cells: (1) Ki-67, expressed by cells in all phases of cell cycle except early G1 and G0 (Schwarting et al., 1986); (2) BrdU, incorporated in the DNA of cells in S phase (Burns et al., 2006); and (3) pH3, a marker for cells in M phase (Norbury and Nurse, 1992). We first assessed proliferation in the CVP taste epithelium of control mice to establish baseline activity. Controls (sham-irradiated) were anesthetized and placed in conical tubes, but not irradiated. We found that $\sim 80 \%$ of basal epithelial cells are Ki-67 immunopositive in control CVP (Fig. $1 A, E$ ), with subsets in S phase $(15 \%)$, indicated by BrdU immunoreactivity assessed at $6 \mathrm{~h}$ postinjection (Figs. $2 A, I$ ) and $\mathrm{M}$ phase (12\%; pH3-IR; Fig. $2 E, J$ ). No dividing cells were observed inside taste buds, consistent with published reports (Beidler and Smallman, 1965; Conger and Wells, 1969; Farbman, 1980; Miura et al., 2003; Hamamichi et al., 2006; but see Sullivan et al., 2010).

We next quantified proliferation in taste epithelia at progressive dpi, and compared these values to those of controls. The labeling index for Ki-67 is significantly reduced compared with controls during the first 3 dpi (Fig. $2 B, E$ ). However, the proportion of dividing cells returns to control levels by $5 \mathrm{dpi}$, and remains at control levels through $21 \mathrm{dpi}$ (Fig. 1C-E). These data demonstrate a clear and rapid effect of irradiation on proliferative activity in the taste progenitor cell population. To further evaluate the effects of irradiation on specific phases of the cell cycle, we monitored the labeling indices for BrdU at $6 \mathrm{~h}$ postinjection ( $\mathrm{S}$ phase) and $\mathrm{pH} 3$ ( $\mathrm{M}$ phase). In sham-irradiated taste tissue, $14.6 \%$ of basal cells have incorporated BrdU and $11.6 \%$ are in $\mathrm{M}$ phase. After irradiation, the labeling indices for cells in $\mathrm{S}$ and $\mathrm{M}$ phases are decreased significantly (5.2 and $4 \%$ at $2 \mathrm{dpi}$, respectively; Fig. 2), which is followed by an overshoot in the proportion of cells in S and $\mathrm{M}$ phases at 5-6 dpi (Fig. 2C,I) and 6 dpi (Fig. $2 G, J$ ), respectively, compared with controls. Labeling indices for cells in $\mathrm{S}$ and $\mathrm{M}$ phases then return to control levels by 7 dpi (Fig. $2 D, H, I, J)$. This biphasic response of proliferating taste progenitor cells to irradiation suggests that proliferation of progenitor cells in the CVP is synchronized and/or accelerated following recovery from radiation.

\section{Irradiation induces cell death in taste epithelium}

In skin and intestinal epithelium, irradiation induces doublestranded breaks in nuclear DNA, which results in mitotic delay, as cells enter cell cycle arrest and attempt to repair damaged DNA (Harper and Elledge, 2007). Cells that fail to adequately repair then undergo apoptosis. In another oral tissue, the salivary gland, irradiation results in maximal cell death within $24 \mathrm{~h}$ (Humphries et al., 2006). Thus, we assessed cell death in taste epithelium via TUNEL at $6,12,18$, and $24 \mathrm{~h}$ postirradiation (hpi). In nonirradiated control tissues, only $0.4 \%$ of basal epithelial cells are TUNEL positive, with only an occasional apoptotic nucleus detected inside a taste bud (Fig. 3A, arrowhead), consistent with published reports (Wang et al., 2007). After irradiation, the
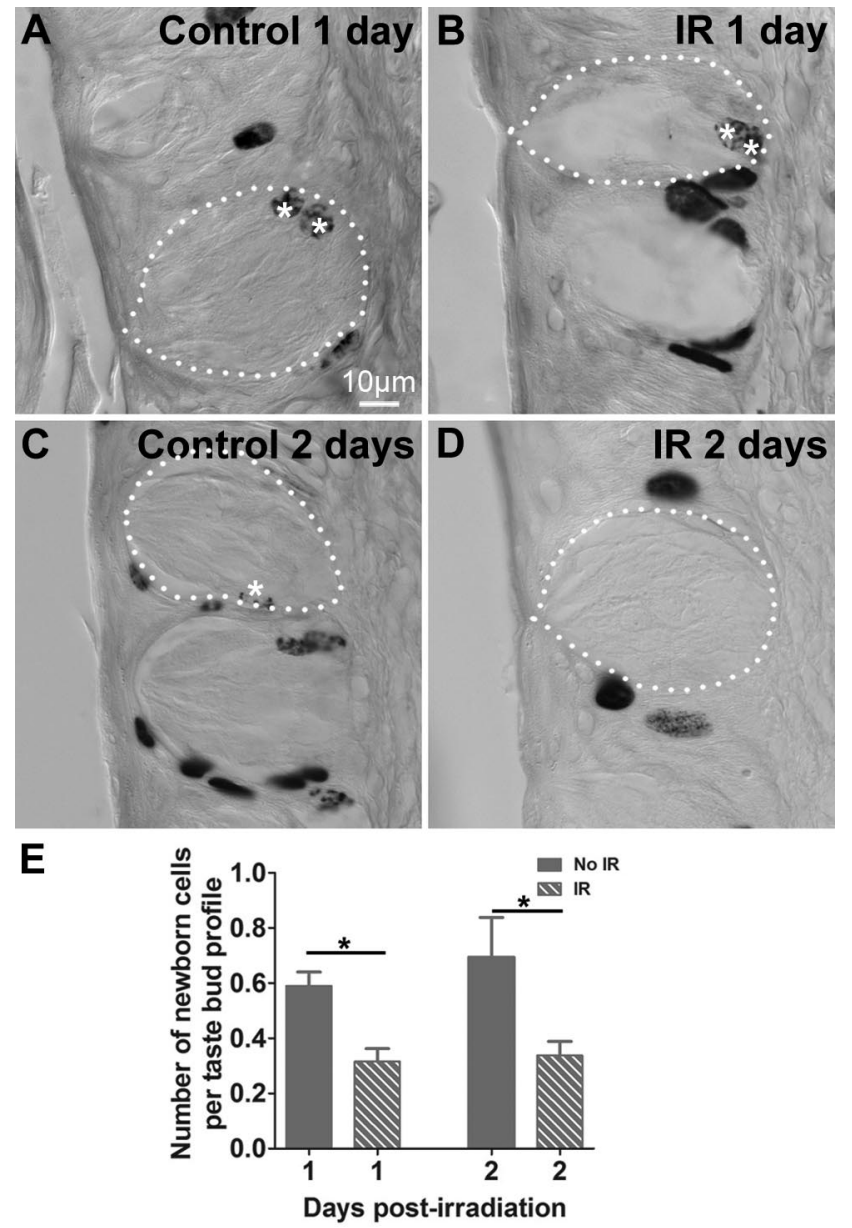

Figure 4. The influx of new cells into taste buds is reduced during the first $2 \mathrm{~d}$ following irradiation. Mice were injected intraperitoneally with BrdU $6 \mathrm{~h}$ before irradiation. BrdU-IR (dark brown) cells inside taste buds were tallied at $1 \mathrm{dpi}(\boldsymbol{A}, \boldsymbol{B})$ and $2 \mathrm{dpi}(\boldsymbol{C}, \boldsymbol{D})$ in irradiated and sham-irradiated control mice. Newborn cells inside taste buds were significantly decreased at 1 and 2 dpi compared with controls $(\boldsymbol{E})$. Dashed lines indicate the borders of individual taste buds. White asterisks, newborn cells inside taste buds marked by BrdU birthdating. $n=3-4$ mice and $90-176$ taste buds per condition and time point. $t$ test, ${ }^{*} p<0.05$.

TUNEL labeling index of basal epithelial cells is significantly increased at $12 \mathrm{hpi}$ and peaks at $18 \mathrm{hpi}$ (Fig. 3B-E, white arrows indicate examples). Although TUNEL labeled only $2.6 \%$ of basal epithelial cells at the peak of cell death, this still represents an $\sim 5$-fold increase over uninjured control levels. Further, considering that TUNEL only reveals the last brief phase of apoptosis (Negoescu et al., 1998), the total number of dying cells is likely much larger. Relatively low, but nonetheless functionally significant, levels of cell death after irradiation have also been reported in epidermis, oral mucosa, and dental stem cells (Morris and Hopewell, 1988; Morris et al., 1993). Importantly, we detected few apoptotic nuclei within irradiated buds (Fig. 3), further suggesting that radiation specifically and initially impacts the dividing taste progenitor cells that reside outside of taste buds. At later time points following radiation, cell death levels resembled that of controls. Specifically, examination of TUNEL-stained CVP sections at 3 and $7 \mathrm{dpi}$ revealed levels of apoptosis which were no different from controls (sham-irradiated, $0.42 \pm 0.06 \%$; $3 \mathrm{dpi}$, $0.48 \pm 0.19 \% ; 7 \mathrm{dpi}, 0.56 \pm 0.20 \%$ TUNEL + basal epithelial cells per CVP, one-way ANOVA, $p=0.11, n=3$ mice per time point). 

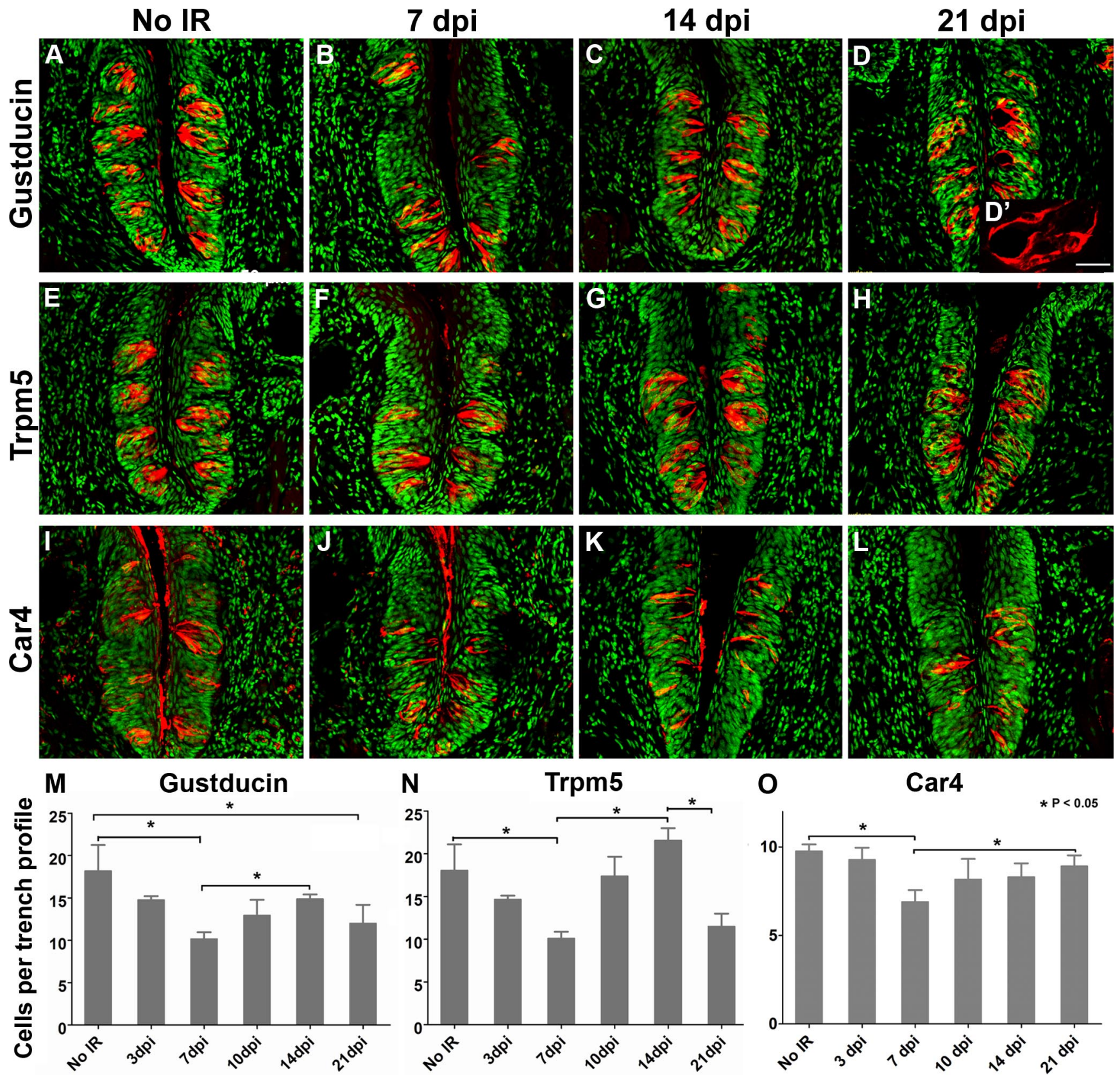

Figure 5. Loss and recovery of differentiated type II and III taste cells is delayed compared with the immediate effect of irradiation on proliferation. Both type II (gustducin-IR; Trpm5-IR, red) and type III cells (Car4-IR, red) are significantly reduced at $7 \mathrm{dpi}$, but not $3 \mathrm{dpi}$. Type II and III cell numbers return to control levels by 14 and $10 \mathrm{dpi}$, respectively. At $21 \mathrm{dpi}$, both gustducin-IR and Trpm5-IR type II cells are lost $(\boldsymbol{M}, \boldsymbol{N})$, while the number of type III cells remains comparable to that of controls (0). Gustducin-IR $(\boldsymbol{A}-\boldsymbol{D})$, Trpm5-IR $(\boldsymbol{E}-\boldsymbol{H})$, Car4-IR $(\boldsymbol{I}-\boldsymbol{L})$, and Sytox (A-L; green). $\boldsymbol{M}-\mathbf{O}$, Histograms of the number of gustducin-, Trpm5-, and Car4-IR cells, respectively, in sham-irradiated control versus irradiated CVPs at progressive days post irradiation. High magnification of gustducin-IR cells at 21 dpi shows their abnormal morphology (D). One-way ANOVA, Tukey's post hoc test; ${ }^{*} p<0.05 . n=3-4$ mice per time point. A total of $134-349$ taste buds was counted per time point and per taste cell type marker. Scale bar: (except D) $50 \mu \mathrm{m}$. Scale bar: (for D), $20 \mu \mathrm{m}$.

Taste bud cells are indirectly affected by irradiation

Within $24 \mathrm{~h}$ of their terminal division within the progenitor pool, postmitotic taste precursor cells move into taste buds, and then, within 2-6 d following birth, differentiate into mature taste cells (Beidler and Smallman, 1965; Cho et al., 1998; Hamamichi et al., 2006; Miura et al., 2006; Oike et al., 2006; Nguyen and Barlow, 2010). As irradiation induces cell cycle arrest and apoptosis of taste progenitor cells (Figs. 1-3), we hypothesized that this cessation of proliferation would lead to a decreased influx of cells into taste buds. To evaluate this possibility, we injected mice with BrdU $6 \mathrm{~h}$ before irradiation, and then compared the number of newborn cells within taste buds of control and irradiated mice that had been killed 1 or $2 \mathrm{~d}$ after irradiation (Fig. 4). The number of BrdU-IR cells inside irradiated taste buds is virtually half that found in controls at both $1 \mathrm{dpi}$ (mean: 0.31 vs 0.59 cells per taste bud profile) and 2 dpi (mean: 0.34 vs 0.69 cells per taste bud profile), indicating that the influx of cells into taste buds is significantly decreased following irradiation.

Next, we tested if differentiated taste receptor cells are directly or indirectly affected by irradiation. If a single $8 \mathrm{~Gy}$ dose targets taste cells directly, we expect that the number of taste cells would decrease within the first few days after irradiation exposure. 
BrdU injected at $5 \mathrm{dpi}$
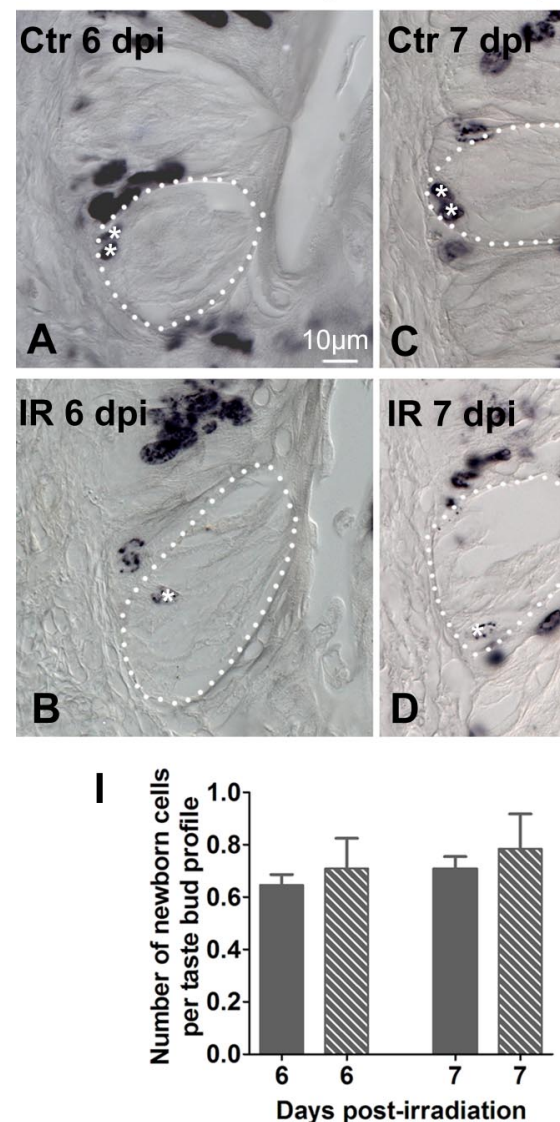

BrdU injected at $6 \mathrm{dpi}$
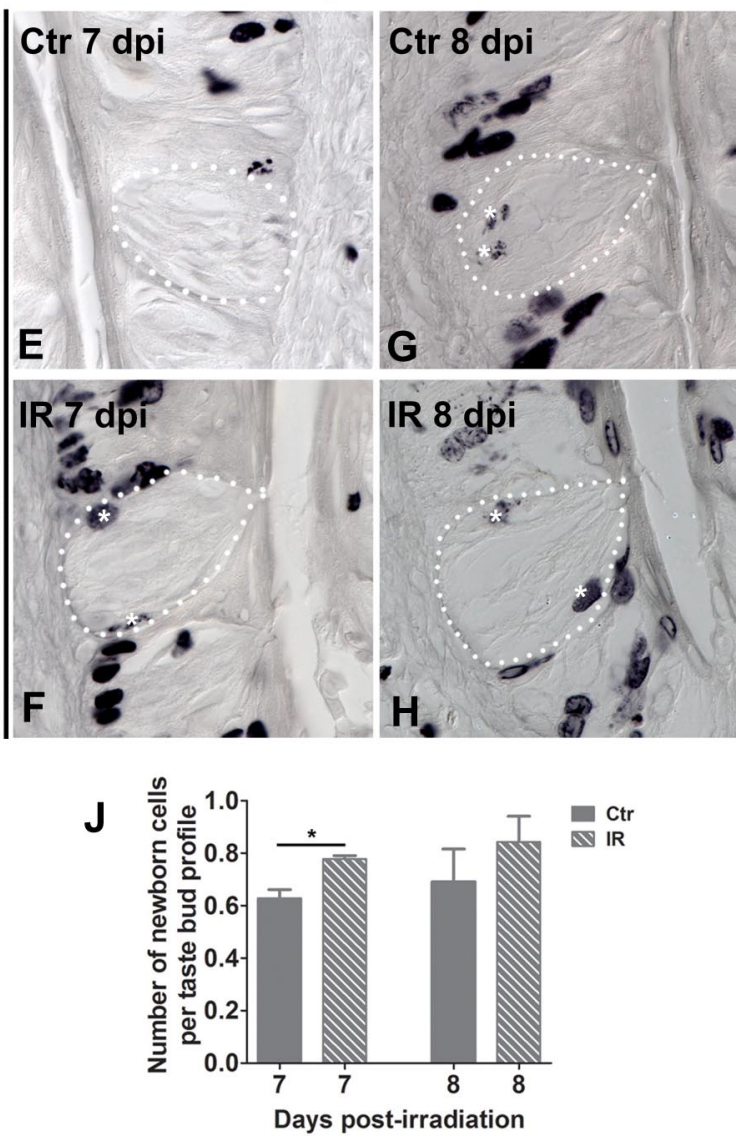

Figure 6. The influx of new cells into taste buds resumes and is accelerated at $6 \mathrm{dpi}$. $\boldsymbol{A}-\boldsymbol{D}, \mathbf{B r d U}$ was injected at $5 \mathrm{dpi}$, and newborn cells inside taste buds quantified at $6 \mathrm{dpi}(\boldsymbol{A}, \boldsymbol{B})$ and $7 \mathrm{dpi}(\boldsymbol{C}$, D) in irradiated and sham-irradiated groups. $\boldsymbol{E}-\boldsymbol{H}$, BrdU was injected at $6 \mathrm{dpi}$, and newborn cells assessed at $7 \mathrm{dpi}(\boldsymbol{E}, \boldsymbol{F})$ and $8 \mathrm{dpi}(\boldsymbol{G}, \boldsymbol{H})$ irradiated (IR) and control (Ctr) $\mathbf{C V P}$ taste buds. Dashed lines indicate borders of taste buds. White asterisks mark newborn cells inside taste buds. The influx of cells into taste buds was significantly accelerated at $7 \mathrm{dpi}$ and assayed at $24 \mathrm{~h}$ following BrdU injection at $6 \mathrm{dpi}(\boldsymbol{J})$, but not at any other time points $(\boldsymbol{I}, \boldsymbol{J}) . t$ test, $n=3$ mice, and $60-183$ taste buds tallied per time point and condition, ${ }^{*} p<0.05$.

However, if the effect of irradiation on taste receptor cells is indirect, i.e., due to a reduction of newborn cells entering taste buds with continued natural cell death of relatively short-lived taste cells, we would expect that the number of taste cells would not decrease until later time points following irradiation. To evaluate these possibilities, we compared the number of two types of differentiated cells in irradiated and control taste buds: type II receptor cells recognized via gustducin-IR (Fig. 5A-D) or Trpm5-IR (Fig. $5 E-H$ ) and type III presynaptic cells that are Car4-IR (Fig. $5 I-L)$. We found that the numbers of type II and III cells did not differ from control values at the early postirradiation time point (3dpi), but both cell types were decreased at 7 dpi (Fig. 5M-O), suggesting that the effects of irradiation on taste cells are indirect. We also tried to quantify type I taste cells via NTPDase2-IR, but because of the complex morphology of type I cells and the localization of NTPdase2 protein at the membrane (Bartel et al., 2006), we could not reliably identify and tally individual type I cells (data not shown). To rule out that the reduction in type II and III cells was due to broad damage of the circumvallate taste papilla, or to total destruction of a subset of taste buds by radiation exposure, we also compared the height of the CVP, and the number of resident taste buds per CVP section, and found no significant differences from controls at $3 \mathrm{dpi}$ or 7 dpi (CVP height: sham-irradiated, $459.77 \pm 40.11 \mu \mathrm{m}$; $3 \mathrm{dpi}$, $453.95 \pm 52.36 \mu \mathrm{m} ; 7 \mathrm{dpi}, 475.00 \pm 44.23 \mu \mathrm{m}$, one-way ANOVA $p=0.31$; number of taste buds per CVP trench profile: shamirradiated, $8.50 \pm 1.69 ; 3 \mathrm{dpi}, 7.95 \pm 1.15$; $7 \mathrm{dpi}, 7.60 \pm 1.30$, oneway $\operatorname{ANOVA} p=0.104, n=3$ mice per time point).
The number of type III cells in irradiated taste buds returned to normal by $10 \mathrm{dpi}$, and remained constant through $21 \mathrm{dpi}$ (Fig. $5 K, L, O)$, consistent with the normal proliferative indices we observed at these later time points (Figs. 1,2). The number of type II cells is also comparable to controls by $14 \mathrm{dpi}$ (Fig. 5C, G, M,N). These findings are broadly similar to those from Yamazaki et al. (2009), who find reduced numbers of type II cells between days 8 and20, but no significant reduction in type III cells during the same period following a single dose of $15 \mathrm{~Gy}$. However, at $21 \mathrm{dpi}$ we observed an apparent second wave of type II cell loss (Fig. $5 D, H, M, N)$, and the remaining type II cells had somewhat abnormal morphology at this late time point (Fig. 5D').

\section{Taste cell regeneration}

Following irradiation, proliferative activity resumes at 5 dpi with higher than normal proportions of cells in $\mathrm{S}$ and $\mathrm{M}$ phases (Figs. $1,2)$. To test if and how this accelerated and/or synchronized proliferation contributes to taste bud regeneration following radiation damage, we tallied the number of newborn taste bud cells in mice that were injected with BrdU, as proliferation resumed at 5 or 6 dpi (Fig. 6). The influx of cells into taste buds was comparable to controls at 6 and $7 \mathrm{dpi}$ following BrdU injection at $5 \mathrm{dpi}$ (Fig. 6A-D,I). Interestingly, when we injected BrdU at $6 \mathrm{dpi}$, significantly more newborn cells were detected in taste buds of irradiated mice than in controls at $24 \mathrm{hpi}$ (7dpi, Fig. 6J; $p>0.05$ ). These data suggest that the transient increase in cells in S and $M$ 


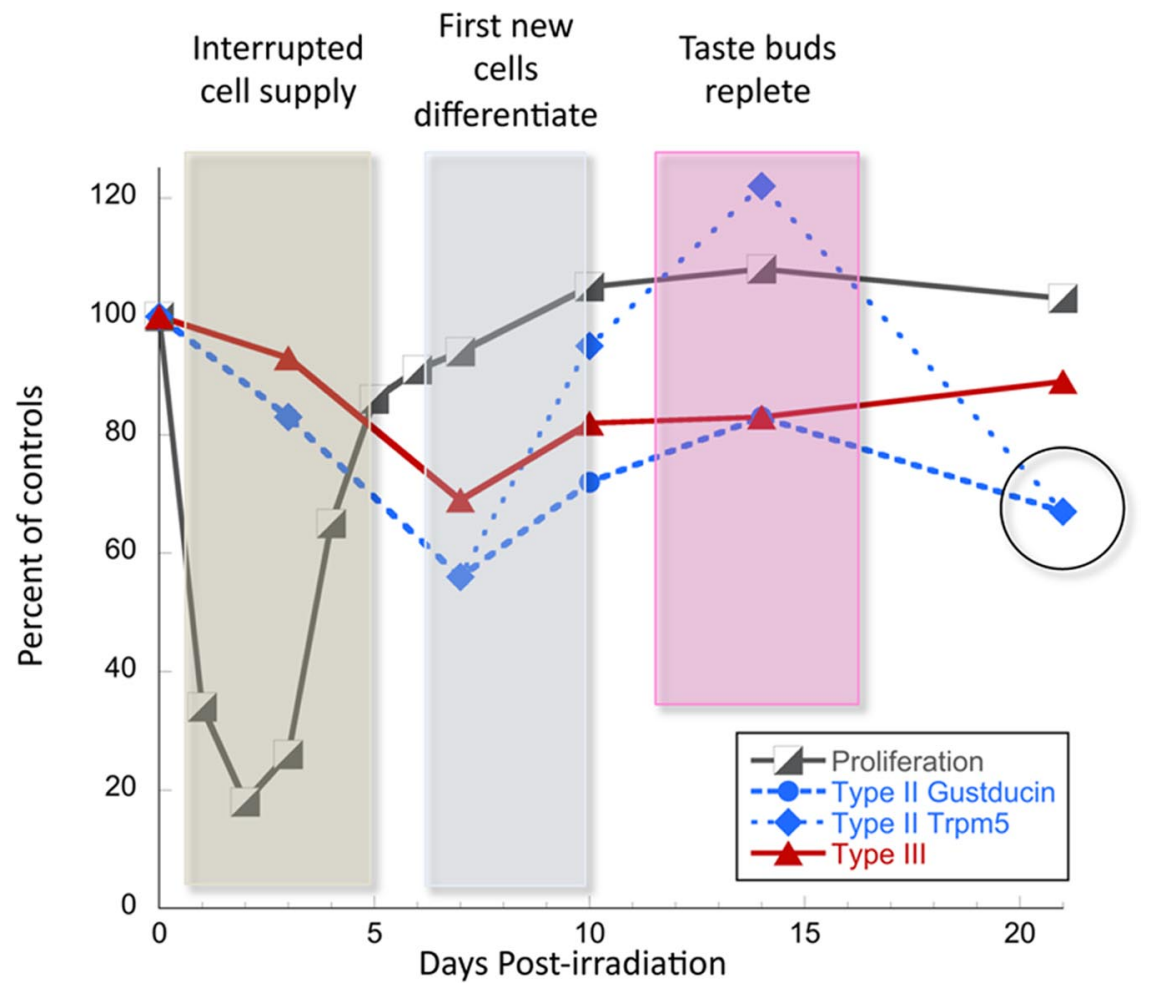

Figure 7. Summary and a model for taste epithelial cell loss and regeneration following irradiation injury. In the first several days following irradiation, taste progenitors arrest the cell cycle (black and white boxes) and their contribution of new cells to taste buds is interrupted (blue box). During this time, the number of both type II (blue squares and circles) and type III (red triangles) cells trend downward, and are significantly reduced by day 7 following radiation. We propose that this loss is due to natural attrition of aged taste cells, which are not replaced by the mitotically arrested progenitor cells. As progenitors resume proliferation, new taste precursor cells enter buds, but these cells require an additional 3-5 d to differentiate (gray box), after which taste cell numbers recover to control values (pink box). Unexpectedly, a second wave of loss of type II taste cells only occurs at 21 dpi (black open circle), which may reflect synchronous, albeit naturally timed death of the cohort of type II cells generated by the burst of proliferative activity $\sim 14 \mathrm{~d}$ prior. The data from Figures 1 and 5 are shown as percentage of controls for this summary diagram.

phase following irradiation also results in a pulsed increase in the supply of new taste receptor cells to taste buds.

\section{Discussion}

Taste loss is a common problem for head and neck cancer patients following radiotherapy. Here we show that a moderate dose of radiation to the head and neck of adult mice directly affects the taste progenitor cells responsible for the continual supply of new cells to taste buds. Within $24 \mathrm{~h}$ of irradiation, actively cycling progenitors are dramatically reduced (Figs. 1, 2); concomitantly, apoptosis of progenitors is significantly increased (Fig. 3). Cell cycle arrest persists for several days, as indicated by significant drops in the proliferative, $\mathrm{S}$ and $\mathrm{M}$ phase indices, while apoptosis in taste progenitors, which likely occurs in cells that fail to repair irradiationinduced DNA damage (Zhou and Sausville, 2003; Nakanishi et al., 2009), peaks within $24 \mathrm{~h}$ (Fig. 3). Both cell cycle arrest and death of progenitors likely contribute to the transient interruption in supply of new taste cells (Fig. 4), but this dearth in cells is not apparent until several days later, when differentiated taste cells are reduced (Fig. 5). In sum, irradiation targets primarily the progenitor pool, which results in a transient but delayed reduction in functional taste cells, as aged taste cells are naturally lost, but are not immediately replaced (Fig. 7).

Following irradiation-induced arrest, proliferation resumes with an accelerated and/or synchronized cell cycle

Tissue-level responses to ionizing radiation depend on the rate of cell renewal (Etoh et al., 1977; Morris, 1996; Wilson, 2007). In human skin, with a 26-75 d turnover, proliferation lags for 4 weeks following radiation, whereas in mouse lip epithelium, which renews in 2-3 d, proliferative arrest lasts 1-2 d (Dörr et al., 1994; Wardley et al., 1998; Potten et al., 2002;). Taste cells renew every 10-14 d (Beidler and Smallman, 1965; Farbman, 1980), a rate congruent with our finding of an intermediate time frame for cell cycle arrest in taste epithelium, i.e., 4-5 d.

When proliferation resumes in irradiated taste epithelium, the proportion of cells in S and M phase increases to levels significantly higher than controls. Similarly, higher proportions of S and M phase cells are observed during regeneration of other tissues following irradiation (Morris, 1996; Dörr et al., 2000). If the regenerative response of taste epithelium is similar to that of other tissues, then increased $S$ and $M$ phase basal cells is due either to production of additional taste bud stem cells (tbSCs) via symmetric divisions, genesis of synchronized transit amplifying cells (TACs) from tbSCs (Lehrer et al., 1998), and/or a shortened cell cycle for TACs (Kavanagh et al., 1995; Dörr, 2003; Ristic-Fira et al., 2007). Distinguishing between these mechanisms, however, is not yet possible, as to date, there are no molecular or functional markers that discriminate tbSCs from TACs (Okubo et al., 2009). Nonetheless, we conclude that proliferation of taste progenitors in general is enhanced during regeneration following damage.

Taste loss is likely due to interruption in delivery of new taste cells combined with continuing natural taste cell loss

Several models have been proposed to account for taste dysfunction following radiotherapy. Irradiation may damage nerve fibers that innervate taste buds, causing taste cell death indirectly (Conger and Wells, 1969; Nelson, 1998), as maintenance of mature taste cells requires nerve contact (Sollars et al., 2002; Miura et al., 2004; Oakley and Witt, 2004). However, at least when examined grossly at the light microscopic level, taste bud innervation appears unperturbed (Conger and Wells, 1969; Yamazaki et al., 2009). Additionally, radiation damage of salivary glands leads to severe hyposalivation, which may contribute to lessened taste acuity (de Graeff et al., 2000; Chambers et al., 2004). However, deficient salivary function is likely not a major driver of taste loss, as taste and salivary gland symptoms vary independently (Porter et al., 2010). In oral mucosa in general (Dörr and Weber-Frisch, 1995; Wardley et al., 1998; Potten et al., 2002), and now specifically in taste epithelium, irradiation targets proliferating cells, resulting in an insufficient supply of new cells to the epithelium and taste buds, respectively. We find that two specific taste cell types are reduced $7 \mathrm{~d}$ after irradiation: type II cells, which transduce sweet, bitter, and umami (Adler et al., 2000; Nelson et al., 2001; Zhang et al., 2003), and type III cells, which mediate sour (Huang et al., 2006) and synapses with taste afferents (Chaudhari and Roper, 2010). The timing for loss of taste cells is broadly 
congruent with the onset of functional taste loss in patients, which is first observed after 1 week of radiotherapy (Mossman and Henkin, 1978), with more broad taste dysfunction in patients by the third or fourth weeks (Ruo Redda and Allis, 2006; Yamashita et al., 2006, 2009; Epstein and Barasch, 2010). In rodent models, changes in sucrose and sodium taste behavioral preferences are also detectable in the first and second weeks following radiation (Nelson, 1998; Yamazaki et al., 2009). However, these studies each entailed delivery of 15-17 Gy to the head, which can cause widespread tissue damage; thus, in addition to targeting mitotic progenitors, postmitotic taste cells may also have been damaged directly (Shatzman and Mossman, 1982; Urek et al., 2005; Fig. 1 in Yamazaki et al., 2009).

Following radiation, tissues typically recover at a pace consistent with the proliferative characteristics of the tissue (Wilson, 2007). For example, regeneration of ventral tongue epithelium following radiation is complete within $15 \mathrm{~d}$ (Dörr and Kummermehr, 1991). Similarly, in taste epithelium, the influx of new cells into taste buds recovers to control levels 1 week after irradiation, and the numbers of type III and II taste cells return to control levels by 10 and 14 dpi, respectively. How does this time frame compare with the timing of taste cell differentiation from the progenitor pool?

Following the last division within the progenitor domain, postmitotic precursors enter taste buds within 12-24 h (Miura et al., 2006; Asano-Miyoshi et al., 2008; Nguyen and Barlow, 2010), and differentiation of type II taste cells is complete between 3 and $6 \mathrm{~d}$ of birth (Cho et al., 1998; Oike et al., 2006); in contrast, little is known of the rate of renewal for cell types I and III. Assuming, however, that each cell lives 10-14 d (Beidler and Smallman, 1965; Farbman, 1980), and taste buds in mice comprise $\sim 60$ cells (Ma et al., 2007), then 4-6 new cells must be both added and lost each day to maintain taste cell complement. Thus, when the supply of new cells is interrupted for 3-4 d by radiation (Fig. 7, blue box), the first loss of differentiated cells is not detected until oldest taste cells (born before irradiation) die on their normal schedule (Zeng and Oakley, 1999; Zeng et al., 2000), while cells that should have replaced them fail to do so (Fig. 7, gray box). By $14 \mathrm{dpi}$, the new cells generated during the regeneration phase (5-7 dpi) have differentiated, hence returning taste buds to their full cell complement (Fig. 7, pink box). We also observed a significant but smaller effect on type III cells. The time needed for differentiation, as well as the lifespan, of type III cells have not been defined. Nonetheless, reduction in type III cells at $7 \mathrm{dpi}$ is consistent with a 3-6 d requirement for differentiation.

Unexpectedly, an apparent second wave of type II, but not type III, taste cell loss was detected at 21 dpi (Fig. 7, circle around type II data points at $21 \mathrm{dpi}$ ). One possibility is that if type II cells live 10-14 d, then a synchronous pulse of new cells into taste buds at 6-8 dpi (Fig. 6) would lead to synchronous death of naturally aged type II cells at $21 \mathrm{dpi}$. Is this late loss of type II, but not type III, cells due to different cell type-specific longevities? For example, if type III cells renew more slowly than type II cells, as has been suggested (Farbman, 1980), but are likewise synchronously generated during regeneration following irradiation, we would predict a second wave of type III cell loss at a later time point following initial recovery. These hypotheses, however, remain to be tested.

\section{Fractional dose radiotherapy likely amplifies the effects of irradiation on taste cell renewal}

Fractionated radiotherapies are used uniformly to treat head and neck cancer. Typically $60-70$ Gy are given $>6-8$ weeks, at $1.8-2$
Gy per day (Sandow et al., 2006; Kamprad et al., 2008). As a result of treatment, $90 \%$ of patients experience taste loss, and while taste function typically recovers, it can take months or years (Conger, 1973; Mossman, 1986; Maes et al., 2002; Shi et al., 2004). We propose that the primary impact of low-dose radiation exposure is on taste progenitors, and this damage response is compounded by daily radiotherapy. We hypothesize that repeated daily radiation results in activation, and therefore damage, of progressively more taste progenitor cells, and this both transiently accelerates and ultimately suppresses regeneration of taste epithelium. Eventually, fractional radiotherapy will lead to the death of most or even all taste progenitor cells, providing an explanation for why recovery of taste function following radiotherapy is slow, ranging from several months to several years, or can be permanent for head and neck cancer patients.

\section{References}

Abercrombie M (1946) Estimation of nuclear population from microtome sections. Anat Rec 94:239-247.

Adler E, Hoon MA, Mueller KL, Chandrashekar J, Ryba NJ, Zuker CS (2000) A novel family of mammalian taste receptors [see comments]. Cell 100:693-702.

Asano-Miyoshi M, Hamamichi R, Emori Y (2008) Cytokeratin 14 is expressed in immature cells in rat taste buds. J Mol Histol 39:193-199.

Bartel DL, Sullivan SL, Lavoie EG, Sévigny J, Finger TE (2006) Nucleoside triphosphate diphosphohydrolase-2 is the ecto-ATPase of type I cells in taste buds. J Comp Neurol 497:1-12.

Beidler LM, Smallman RL (1965) Renewal of cells within taste buds. J Cell Biol 27:263-272.

Bernhardt SJ, Naim M, Zehavi U, Lindemann B (1996) Changes in IP3 and cytosolic $\mathrm{Ca} 2+$ in response to sugars and non-sugar sweeteners in transduction of sweet taste in the rat. J Physiol 490 (Pt 2):325-336.

Boughter JD Jr, Pumplin DW, Yu C, Christy RC, Smith DV (1997) Differential expression of alpha-gustducin in taste bud populations of the rat and hamster. J Neurosci 17:2852-2858.

Burns TC, Ortiz-González XR, Gutíerrez-Pérez M, Keene CD, Sharda R, Demorest ZL, Jiang Y, Nelson-Holte M, Soriano M, Nakagawa Y, Luquin MR, Garcia-Verdugo JM, Prósper F, Low WC, Verfaillie CM (2006) Thymidine analogs are transferred from prelabeled donor to host cells in the central nervous system after transplantation: a word of caution. Stem Cells 24:1121-1127.

Chambers MS, Garden AS, Kies MS, Martin JW (2004) Radiation-induced xerostomia in patients with head and neck cancer: pathogenesis, impact on quality of life, and management. Head Neck 26:796-807.

Chandrashekar J, Yarmolinsky D, von Buchholtz L, Oka Y, Sly W, Ryba NJ, Zuker CS (2009) The taste of carbonation. Science 326:443-445.

Chaudhari N, Roper SD (2010) The cell biology of taste. J Cell Biol 190:285-296.

Cho YK, Farbman AI, Smith DV (1998) The timing of alpha-gustducin expression during cell renewal in rat vallate taste buds. Chem Senses 23:735-742.

Clapp TR, Stone LM, Margolskee RF, Kinnamon SC (2001) Immunocytochemical evidence for co-expression of Type III IP3 receptor with signaling components of bitter taste transduction. BMC Neurosci 2:6.

Clapp TR, Yang R, Stoick CL, Kinnamon SC, Kinnamon JC (2004) Morphologic characterization of rat taste receptor cells that express components of the phospholipase C signaling pathway. J Comp Neurol 468:311-321.

Clapp TR, Medler KF, Damak S, Margolskee RF, Kinnamon SC (2006) Mouse taste cells with $\mathrm{G}$ protein-coupled taste receptors lack voltagegated calcium channels and SNAP-25. BMC Biol 4:7.

Conger AD (1973) Loss and recovery of taste acuity in patients irradiated to the oral cavity. Radiat Res 53:338-347.

Conger AD, Wells MA (1969) Radiation and aging effect on taste structure and function. Radiat Res 37:31-49.

de Graeff A, de Leeuw JR, Ros WJ, Hordijk GJ, Blijham GH, Winnubst JA (2000) Long-term quality of life of patients with head and neck cancer. Laryngoscope 110:98-106.

Donaldson SS (1977) Nutritional consequences of radiotherapy. Cancer Res 37:2407-2413. 
Dörr W (2003) Modulation of repopulation processes in oral mucosa: experimental results. Int J Radiat Biol 79:531-537.

Dörr W, Kummermehr J (1991) Proliferation kinetics of mouse tongue epithelium under normal conditions and following single dose irradiation. Virchows Arch B Cell Pathol Incl Mol Pathol 60:287-294.

Dörr W, Weber-Frisch M (1995) Repopulation response of mouse oral mucosa during unconventional radiotherapy protocols. Radiother Oncol $37: 230-236$.

Dörr W, Emmendörfer H, Haide E, Kummermehr J (1994) Proliferation equivalent of 'accelerated repopulation' in mouse oral mucosa. Int J Radiat Biol 66:157-167.

Dörr W, Brankovic K, Hartmann B (2000) Repopulation in mouse oral mucosa: changes in the effect of dose fractionation. Int J Radiat Biol 76:383-390.

Dvoryanchikov G, Tomchik SM, Chaudhari N (2007) Biogenic amine synthesis and uptake in rodent taste buds. J Comp Neurol 505:302-313.

Epstein JB, Barasch A (2010) Taste disorders in cancer patients: pathogenesis, and approach to assessment and management. Oral Oncol 46:77-81.

Etoh H, Taguchi YH, Tabachnick J (1977) Cytokinetics of regeneration in beta-irradiated guinea-pig epidermis. Radiat Res 71:109-118.

Farbman AI (1980) Renewal of taste bud cells in rat circumvallate papillae. Cell Tissue Kinet 13:349-357.

Hamamichi R, Asano-Miyoshi M, Emori Y (2006) Taste bud contains both short-lived and long-lived cell populations. Neuroscience 141:2129-2138

Harper JW, Elledge SJ (2007) The DNA damage response: ten years after. Mol Cell 28:739-745.

Huang AL, Chen X, Hoon MA, Chandrashekar J, Guo W, Tränkner D, Ryba NJ, Zuker CS (2006) The cells and logic for mammalian sour taste detection. Nature 442:934-938.

Huang YJ, Lu KS (2001) TUNEL staining and electron microscopy studies of apoptotic changes in the guinea pig vallate taste cells after unilateral glossopharyngeal denervation. Anat Embryol (Berl) 204:493-501.

Huang YJ, Maruyama Y, Lu KS, Pereira E, Plonsky I, Baur JE, Wu D, Roper SD (2005) Mouse taste buds use serotonin as a neurotransmitter. J Neurosci 25:843-847.

Humphries MJ, Limesand KH, Schneider JC, Nakayama KI, Anderson SM, Reyland ME (2006) Suppression of apoptosis in the protein kinase Cdelta null mouse in vivo. J Biol Chem 281:9728-9737.

Ichimori Y, Ueda K, Okada H, Honma S, Wakisaka S (2009) Histochemical changes and apoptosis in degenerating taste buds of the rat circumvallate papilla. Arch Histol Cytol 72:91-100.

Jensen SB, Pedersen AM, Reibel J, Nauntofte B (2003) Xerostomia and hypofunction of the salivary glands in cancer therapy. Support Care Cancer 11:207-225.

Kamprad F, Ranft D, Weber A, Hildebrandt G (2008) Functional changes of the gustatory organ caused by local radiation exposure during radiotherapy of the head-and-neck region. Strahlenther Onkol 184:157-162.

Kataoka S, Yang R, Ishimaru Y, Matsunami H, Sévigny J, Kinnamon JC, Finger TE (2008) The candidate sour taste receptor, PKD2L1, is expressed by type III taste cells in the mouse. Chem Senses 33:243-254.

Kavanagh BD, Lin PS, Chen P, Schmidt-Ullrich RK (1995) Radiationinduced enhanced proliferation of human squamous cancer cells in vitro: a release from inhibition by epidermal growth factor. Clin Cancer Res $1: 1557-1562$.

Lawton DM, Furness DN, Lindemann B, Hackney CM (2000) Localization of the glutamate-aspartate transporter, GLAST, in rat taste buds. Eur J Neurosci 12:3163-3171.

Lehrer MS, Sun TT, Lavker RM (1998) Strategies of epithelial repair: modulation of stem cell and transit amplifying cell proliferation. J Cell Sci 111 (Pt 19):2867-2875.

Ma H, Yang R, Thomas SM, Kinnamon JC (2007) Qualitative and quantitative differences between taste buds of the rat and mouse. BMC Neurosci 8:5.

Maes A, Huygh I, Weltens C, Vandevelde G, Delaere P, Evers G, Van den Bogaert W (2002) De Gustibus: time scale of loss and recovery of tastes caused by radiotherapy. Radiother Oncol 63:195-201.

Miura H, Kusakabe Y, Kato H, Miura-Ohnuma J, Tagami M, Ninomiya Y, Hino A (2003) Co-expression pattern of Shh with Proxl and that of Nkx2.2 with Mash1 in mouse taste bud. Gene Expr Patterns 3:427-430.

Miura H, Kato H, Kusakabe Y, Tagami M, Miura-Ohnuma J, Ninomiya Y, Hino A (2004) A strong nerve dependence of sonic hedgehog expression in basal cells in mouse taste bud and an autonomous transcriptional control of genes in differentiated taste cells. Chem Senses 29:823-831.

Miura H, Kusakabe Y, Harada S (2006) Cell lineage and differentiation in taste buds. Arch Histol Cytol 69:209-225.

Miyoshi MA, Abe K, Emori Y (2001) IP(3) receptor type 3 and PLCbeta2 are co-expressed with taste receptors $\mathrm{T} 1 \mathrm{R}$ and $\mathrm{T} 2 \mathrm{R}$ in rat taste bud cells. Chem Senses 26:259-265.

Morris GM (1996) Review article: effects of radiation on the cell proliferation kinetics of epithelial tissues-therapeutic implications. Br J Radiol 69:795-803.

Morris GM, Hopewell JW (1988) Changes in the cell kinetics of pig epidermis after single doses of $\mathrm{X}$ rays. Br J Radiol 61:205-211.

Morris GM, Landuyt W, Whitehouse E, Vanuytsel L, Hopewell JW (1993) Radiation response of mouse lip mucosal epithelium: a cell kinetic study. Int J Radiat Biol 63:509-517.

Mossman KL (1986) Gustatory tissue injury in man: radiation dose response relationships and mechanisms of taste loss. Br J Cancer [Suppl] 7:9-11.

Mossman KL, Henkin RI (1978) Radiation-induced changes in taste acuity in cancer patients. Int J Radiat Oncol Biol Phys 4:663-670.

Murray RG (1986) The mammalian taste bud type III cell: a critical analysis. J Ultrastruct Mol Struct Res 95:175-188.

Nakanishi M, Niida H, Murakami H, Shimada M (2009) DNA damage responses in skin biology-implications in tumor prevention and aging acceleration. J Dermatol Sci 56:76-81.

Negoescu A, Guillermet C, Lorimier P, Brambilla E, Labat-Moleur F (1998) Importance of DNA fragmentation in apoptosis with regard to TUNEL specificity. Biomed Pharmacother 52:252-258.

Nelson GM (1998) Biology of taste buds and the clinical problem of taste loss. Anat Rec 253:70-78.

Nelson G, Hoon MA, Chandrashekar J, Zhang Y, Ryba NJ, Zuker CS (2001) Mammalian sweet taste receptors. Cell 106:381-390.

Nguyen HM, Barlow LA (2010) Differential expression of a BMP4 reporter allele in anterior fungiform versus posterior circumvallate taste buds of mice. BMC Neurosci 11:129.

Norbury C, Nurse P (1992) Animal cell cycles and their control. Annu Rev Biochem 61:441-470.

Oakley B, Witt M (2004) Building sensory receptors on the tongue. J Neurocytol 33:631-646.

Oike H, Matsumoto I, Abe K (2006) Group IIA phospholipase A(2) is coexpressed with SNAP-25 in mature taste receptor cells of rat circumvallate papillae. J Comp Neurol 494:876-886.

Okubo T, Clark C, Hogan BL (2009) Cell lineage mapping of taste bud cells and keratinocytes in the mouse tongue and soft palate. Stem Cells 27:442-450.

Porter SR, Fedele S, Habbab KM (2010) Taste dysfunction in head and neck malignancy. Oral Oncol 46:457-459.

Potten CS, Booth D, Cragg NJ, Tudor GL, O'Shea JA, Booth C, Meineke FA, Barthel D, Loeffler M (2002) Cell kinetic studies in the murine ventral tongue epithelium: mucositis induced by radiation and its protection by pretreatment with keratinocyte growth factor (KGF). Cell Prolif 35 [Suppl] 1:32-47.

Pumplin DW, Getschman E, Boughter JD Jr, Yu C, Smith DV (1999) Differential expression of carbohydrate blood-group antigens on rat tastebud cells: relation to the functional marker alpha-gustducin. J Comp Neurol 415:230-239.

Ristic-Fira AM, Todorovic DV, Koricanac LB, Petrovic IM, Valastro LM, Cirrone PG, Raffaele L, Cuttone G (2007) Response of a human melanoma cell line to low and high ionizing radiation. Ann N Y Acad Sci 1095:165-174.

Ruo Redda MG, Allis S (2006) Radiotherapy-induced taste impairment. Cancer Treat Rev 32:541-547.

Sandow PL, Hejrat-Yazdi M, Heft MW (2006) Taste loss and recovery following radiation therapy. J Dent Res 85:608-611.

Schwarting R, Gerdes J, Niehus J, Jaeschke L, Stein H (1986) Determination of the growth fraction in cell suspensions by flow cytometry using the monoclonal antibody Ki-67. J Immunol Methods 90:65-70.

Schwartz LK, Weiffenbach JM, Valdez IH, Fox PC (1993) Taste intensity performance in patients irradiated to the head and neck. Physiol Behav 53:671-677.

Shatzman AR, Mossman KL (1982) Radiation effects on bovine taste bud membranes. Radiat Res 92:353-358. 
Shi HB, Masuda M, Umezaki T, Kuratomi Y, Kumamoto Y, Yamamoto T, Komiyama S (2004) Irradiation impairment of umami taste in patients with head and neck cancer. Auris Nasus Larynx 31:401-406.

Sollars SI, Smith PC, Hill DL (2002) Time course of morphological alterations of fungiform papillae and taste buds following chorda tympani transection in neonatal rats. J Neurobiol 51:223-236.

Sullivan JM, Borecki AA, Oleskevich S (2010) Stem and progenitor cell compartments within adult mouse taste buds. Eur J Neurosci 31:1549-1560.

Takeda M, Suzuki Y, Obara N, Nagai Y (1992) Neural cell adhesion molecule of taste buds. J Electron Microsc 41:375-380.

Urek MM, Bralic M, Tomac J, Borcic J, Uhac I, Glazar I, Antonic R, Ferreri S (2005) Early and late effects of X-irradiation on submandibular gland: a morphological study in mice. Arch Med Res 36:339-343.

Vandenbeuch A, Clapp TR, Kinnamon SC (2008) Amiloride-sensitive channels in type I fungiform taste cells in mouse. BMC Neurosci 9:1.

Vissink A, Jansma J, Spijkervet FK, Burlage FR, Coppes RP (2003) Oral sequelae of head and neck radiotherapy. Crit Rev Oral Biol Med 14:199-212.

Wang H, Zhou M, Brand J, Huang L (2007) Inflammation activates the interferon signaling pathways in taste bud cells. J Neurosci 27:10703-10713.

Wardley AM, Booth D, Roberts SA, Scarffe JH, Potten CS (1998) A quantitative histometric murine in vivo model of radiation-induced oral mucositis. Arch Oral Biol 43:567-577.

Wilson GD (2007) Cell kinetics. Clin Oncol (R Coll Radiol) 19:370-384.

Yamashita H, Nakagawa K, Nakamura N, Abe K, Asakage T, Ohmoto M, Okada S, Matsumoto I, Hosoi Y, Sasano N, Yamakawa S, Ohtomo K (2006) Relation between acute and late irradiation impairment of four basic tastes and irradiated tongue volume in patients with head-and-neck cancer. Int J Radiat Oncol Biol Phys 66:1422-1429.

Yamashita H, Nakagawa K, Hosoi Y, Kurokawa A, Fukuda Y, Matsumoto I, Misaka T, Abe K (2009) Umami taste dysfunction in patients receiving radiotherapy for head and neck cancer. Oral Oncol 45:e19-23.

Yamazaki M, Fujii S, Ochiai A (2009) Reduction of type II taste cells correlates with taste dysfunction after X-ray irradiation in mice. J Oral Pathol Med 39:212-218.

Yang R, Crowley HH, Rock ME, Kinnamon JC (2000) Taste cells with synapses in rat circumvallate papillae display SNAP-25-like immunoreactivity. J Comp Neurol 424:205-215.

Yang R, Ma H, Thomas SM, Kinnamon JC (2007) Immunocytochemical analysis of syntaxin-1 in rat circumvallate taste buds. J Comp Neurol 502:883-893.

Yee CL, Yang R, Böttger B, Finger TE, Kinnamon JC (2001) “Type III” cells of rat taste buds: immunohistochemical and ultrastructural studies of neuron-specific enolase, protein gene product 9.5, and serotonin. J Comp Neurol 440:97-108.

Zeng Q, Oakley B (1999) p53 and Bax: putative death factors in taste cell turnover. J Comp Neurol 413:168-180.

Zeng Q, Kwan A, Oakley B (2000) Gustatory innervation and baxdependent caspase-2: participants in the life and death pathways of mouse taste receptor cells. J Comp Neurol 424:640-650.

Zhang Y, Hoon MA, Chandrashekar J, Mueller KL, Cook B, Wu D, Zuker CS, Ryba NJ (2003) Coding of sweet, bitter, and umami tastes: different receptor cells sharing similar signaling pathways. Cell 112:293-301.

Zhou BB, Sausville EA (2003) Drug discovery targeting Chk1 and Chk2 kinases. Prog Cell Cycle Res 5:413-421. 